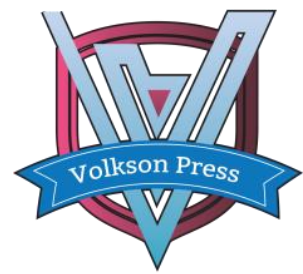

Contents List available at VOLKSON PRESS

Economics \& Management Innovations(EMI)

DOI : http://doi.org/10.26480/icemi.01.2017.124.125

\title{
The Relationship between Nostalgic Emotion and Purchase Intention: Brand Awareness and Brand Attitude as Moderating Variables
}

\author{
Yu-Pei Kuo ${ }^{1 *}$, Yi-Xian Wang² \\ ${ }^{1}$ Art Design at China-ASEAN International College, Dhurakij Pundit University, Thailand \\ ${ }^{2}$ MBA at China-ASEAN International College, Dhurakij Pundit University, Thailand \\ *yu-pei.kuo@dpu.ac.th \\ This is an open access article distributed under the Creative Commons Attribution License, which permits unrestricted use, distribution, and reproduction in any \\ medium, provided the original work is properly cited.
}

\section{ARTICLE DETAILS}

\section{Article History:}

Received 02 october 2017 Accepted 06 october 2017 Available online 11 october 2017

\section{Keywords:}

nostalgic emotion, brand identity, brand attitude, purchase intention, food

\section{ABSTRACT}

The purpose of this paper is to explore the influence of nostalgic emotion, brand awareness, and brand attitude on purchase intention. Although previous literature has discussed nostalgic emotion more than visual communication and corporate marketing, it has only looked at the influence of nostalgia on consumer behavior, while ignoring the purchase intention generated by nostalgic brand factors. Therefore, the present study proposes a research model and questionnaire, and discusses the effect of brand awareness and attitude on the relationship between the nostalgic elements of food brands and purchase intention. The results show that there is a significant positive relationship between the purchase intention of consumers and nostalgic elements. Brand awareness and brand attitude have a significant positive moderating effect on the relationship between nostalgic elements and purchase intention. Finally, we discuss the implications of our findings.

\section{Introduction}

The role of emotional factors in the purchasing decisions of consumers cannot be ignored. Among the strengths and strategic actions of various industries, nostalgic emotion has become an important product strategy for many heritage brands in the hope of converting the emotional memories of consumers into purchasing power in order to withstand the threat of new or international brands. In this area, food brands have the most potential (Kessous, 2015; Tirelli \& Martínez-Ruiz, 2014). The food products are a product type that is likely to generate purchase intention (Yeh \& Huan, 2017). Research on nostalgic emotion is still in its infancy, and there is a lack of research on how factors such as brand awareness and brand attitude affect nostalgic purchase intention. In addition, the focus of this study on nostalgic elements, brand awareness, brand attitude, and purchase intention in the market of food products has rarely been explored in previous research. The present study addresses this gap in the previous literature, using the nostalgic emotional needs of consumers as a basis for exploring nostalgia, brand awareness, brand attitude, and purchase intention. Next, we develop the model and measures for the present study in order to put forward specific measures for current nostalgia brand marketing, expanding brand awareness, encouraging consumers' purchase intention, and realizing the marketing breakthrough and innovation of nostalgia brands.

\section{Research Framework and Methods}

The present study explores the influence of nostalgic elements, brand image, and brand attitude on purchase intention, developing a research model and measurements. Therefore, the present study integrates the current literature to define nostalgic emotion and brand, and develop a research model. First, nostalgic emotion is a longing for a past emotional response, and its causes are often related to individual experiences. Nostalgic emotion is not simply about feelings; it also has deep social and political meaning. In addition, nostalgia is a type of perceived memory, and may not necessarily be a good memory (Bambauer-Sachse \& Gierl, 2009). Second, Wang et al. (2017) asserted that brand attitude is the overall evaluation of a company generated by consumers, which influences subsequent consumer behavior. The present study defines brand attitude, including its three components, as follows: an individual's persistent and consistent positive or negative overall assessment of a brand, including emotional, belief, and behavioral aspects. Finally, Knapp et al. (2001) explained that brand image is the awareness of a brand in the minds of consumers, helping consumers establish brand attitude and confidence, further affecting their spending willingness and behavior. Therefore, the present study argues that the brand awareness attributes for nostalgia brands tend to focus on physical elements, such as color, size, shape, and nostalgia packaging. Nostalgia in brand awareness can help customers establish brand attitude and confidence (Chen et al., 2014). Finally, the present study combines nostalgic elements, brand awareness, and brand attitude as the variables, developing a research model (Figure 1) and exploring the impact of nostalgia in brand awareness and brand attitude on consumers' purchase intention toward food products.

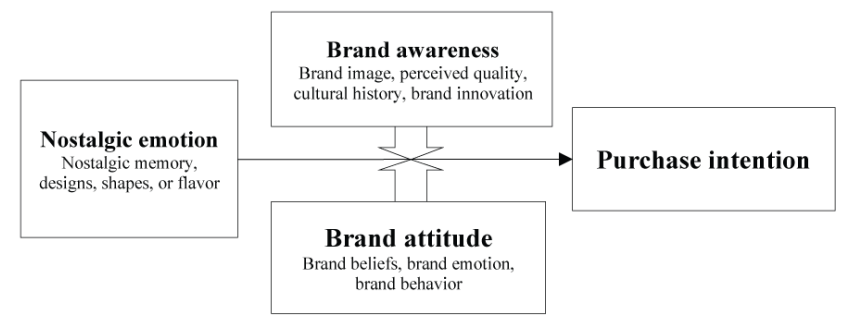

Figure 1: Research Framework

Based on the review of the literature above, we examine the effect of "nostalgic elements," "brand awareness," and "brand attitude" on "purchase intention," including characteristics of food product nostalgia, to develop a research model. We develop three hypotheses from the research model as follows:

H1: Nostalgic emotion has a positive influence on purchase intention.

H2: Nostalgic emotion has a significant influence on purchase intention under the moderating effect of brand awareness.

H3: Nostalgic emotion has a significant influence on purchase intention under the moderating effect of brand attitude.

3. Data Collection and Analysis 
The present study distributed and received, in return, 600 questionnaires electronically, producing a response rate of $100 \%$. There are 541 valid questionnaires, producing an effective response rate of $90.2 \%$. In terms of reliability, the present study used Cronbach's $\alpha$ on each of the dimensions. Each of the dimensions has a Cronbach's $\alpha$ greater than 0.8 , meaning that the questionnaire has good consistency. In terms of validity, the present study used confirmatory analysis. Table 1 shows that most of the results of the confirmatory analysis meet the standard criteria, with only GFI and AGFI slightly lower than the standard criteria, and greater than 0.58 , indicating that the model has a good fit. Meanwhile, the CR and AVE for each of the dimensions are larger than 0.5 , indicating that the questionnaire has good convergent validity. Finally, the square AVE for each of the dimensions is greater than their correlation coefficients, representing good discriminant validity.

\section{Table 1 Model Fit Analysis}

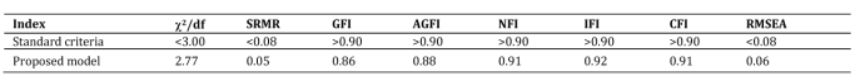

Based on a Summary of hypothesis validation in Table 2, firstly, the regression results at Model 2 show that nostalgic emotion has a significant influence on purchase intention ( $\beta$ coefficient $=\mathbf{0 . 5 6 5}$, $p$ value $<0.001$ ), which means that H1: 'nostalgic emotion has a significant positive influence on purchase intention' is supported. Secondly, the regression results at Model 3 show that brand awareness does not have a significant moderating role in the relationship between nostalgic emotion and purchase intention (p-value $>0.05$ ), which means that H4: 'nostalgic emotion has a significant influence on purchase intention under the moderating effect of brand awareness' is not supported. Finally, the regression results at Model 6 show that brand attitude has a significant moderating role in the relationship between nostalgic emotion and purchase intention $(\beta$ coefficient $=$ 0.240 , p value $<0.05$ ), which means that $H 3$ : 'nostalgic emotion has a significant influence on purchase intention under the moderating effect of brand attitude' is supported.

Table 2 The Regression for Summary of Hypothesis Validation

\begin{tabular}{|c|c|c|c|c|}
\hline Item & Model & Model 2 & Model 3 & Model 4 \\
\hline Sex & .027 & .006 & .006 & .005 \\
\hline Age & .009 & -.007 & -.008 & -.006 \\
\hline Education & -.043 & -.008 & -.008 & -.008 \\
\hline $\begin{array}{l}\text { Average } \\
\text { monthly } \\
\text { income }\end{array}$ & -.015 & .033 & .033 & .033 \\
\hline $\begin{array}{l}\text { Number } \\
\text { purchases }\end{array}$ & .042 & .016 & .016 & .016 \\
\hline $\begin{array}{l}\text { Nostalgic } \\
\text { emotion }\end{array}$ & -- & $.108^{* * *}$ & $.107 * * *$ & $.115^{* * *}$ \\
\hline $\begin{array}{l}\text { Brand } \\
\text { awareness }\end{array}$ & -- & $.232^{* * *}$ & $.232^{* * *}$ & $.231^{* * *}$ \\
\hline Brand attitude & -- & $.533^{* * *}$ & $.533^{* * *}$ & $.529 * * *$ \\
\hline $\begin{array}{l}\text { Nostalgic } \\
\text { emotion } \\
\text { brand } \\
\text { awareness }\end{array}$ & --- & --- & -0.006 & -- \\
\hline $\begin{array}{l}\text { Nostalgic } \\
\text { emotion } \times \\
\text { brand attitude }\end{array}$ & --- & --- & --- & $0.024 * * *$ \\
\hline$\overline{A d j R^{2}}$ & -0.004 & 0.652 & 0.652 & 0.652 \\
\hline$\Delta R^{2}$ & 0.005 & 0.657 & 0.657 & 0.658 \\
\hline F & 0.581 & $141.324^{* * *}$ & $125.426^{* * *}$ & $125.65^{* * *}$ \\
\hline
\end{tabular}

\section{Conclusions and Recommendations}

Based on our analysis (see Table 2), we found a significant positive relationship between the purchase intention of consumers and nostalgic elements. In addition, the individual characteristics of consumers also impact purchase intention. For example, consumers' purchase intention for nostalgia products increases with age. In addition, there are differences in the levels of the relationship of different nostalgic elements with purchase intention (Barauskaite \& Gineikiene, 2017). In particular, nostalgic designs are better able to stimulate consumers' purchase intention followed by taste. Meanwhile, the brand attitude and brand awareness have a moderating effect on the relationship between nostalgic emotion and purchase intention (Shin \& Parker, 2017; Whan Park et al., 2010). We found that under the moderating effect of brand awareness, nostalgic emotion does not have a significant influence on purchase intention. Under the moderating effect of brand attitude, nostalgic emotion has a significant positive influence on purchase intention. Our findings showed that brand innovation in the food product industry has a significant moderating effect on purchase intention (Tsai \& Wang, 2017) regardless of whether brand expression is conveyed through brand nostalgia design or shape. In summary, brands utilize nostalgic elements to stimulate positive emotions in consumers, linking products and increasing the purchase intention of consumers. The data analysis in the present study can provide some reference for nostalgia marketing in the food product industry. However, research on the influence of nostalgia on consumer attitude and behavior in different industries and for different products will still be required in order to strengthen research on the purchase behavior toward nostalgia products.

\section{Reference}

[1] Bambauer-Sachse, S. \& Gierl, H. 2009. Effects of nostalgic advertising through emotions and the intensity of the evoked mental images. Advances in Consumer Research, 36: 391-398.

[2] Barauskaite, D. \& Gineikiene, J. 2017. Nostalgia may not work for everyone: The case of innovative consumers. Organizations and Markets in Emerging Economies, 8(1): 33-43.

[3] Chen, H. B., Yeh, S. S., \& Huan, T. C. 2014. Nostalgic emotion, experiential value, brand image, and consumption intentions of customers of nostalgic-themed restaurants. Journal of Business Research, 67(3): 354-360.

[4] Kessous, A. 2015. Nostalgia and brands: A sweet rather than a bitter cultural evocation of the past. Journal of Marketing Management 31(17-18): 1899-1923.

[5] Knapp, J., Kausch, A., Auer, C., \& Brand, M. 2001. Transformation of Rhododendron through microprojectile bombardment. Plant Cell Reports, 20(8): 749-754.

[6] Shin, H. \& Parker, J. 2017. Exploring the elements of consumer nostalgia in retailing: Evidence from a content analysis of retailer collages. Journal of Retailing and Consumer Services, 35: 1-11.

[7] Tirelli, C. \& Martínez-Ruiz, M. P. 2014. Influences of product attributes on sojourners' food purchase decisions. British Food Journal, 116(2): 251-271.

[8] Tsai, C. T. S. \& Wang, Y. C. 2017. Experiential value in branding food tourism. Journal of Destination Marketing and Management, 6(1): 56-65.

[9] Wang, S. W., Kao, G. H. Y., \& Ngamsiriudom, W. 2017. Consumers' attitude of endorser credibility, brand and intention with respect to celebrity endorsement of the airline sector. Journal of Air Transport Management, 60: 10-17.

[10] Whan Park, C., MacInnis, D. J., Priester, J., Eisingerich, A. B., \& Iacobucci, D. 2010. Brand attachment and brand attitude strength: Conceptual and empirical differentiation of two critical brand equity drivers. Journal of Marketing, 74(6): 1-17.

[11] Yeh, S. S. \& Huan, T. C. 2017. Assessing the impact of work environment factors on employee creative performance of finedining restaurants. Tourism Management, 58: 119-131. 